\title{
HUBUNGAN DUKUNGAN KELUARGA DENGAN KUALITAS HIDUP PENDERITA TUBERKULOSIS
}

\section{Relationship Of Family Support With Quality Of Life Of Patients Tuberculosis}

\section{Candra Saputra I'}

*STIKes EKA HARAP, Palangka Raya, Kalimantan Tengah, Indonesia

*email: cnnsaputra@gmail.com

\begin{abstract}
Abstrak
Latar Belakang : Tuberkulosis (TBC) adalah suatu penyakit menular yang disebabkan oleh kuman mycobacterium tuberculosis. Fenomena yang didapatkan di masyarakat sekarang ini masih ada anggota keluarga yang merasa takut berdekatan dengan seseorang yang menderita tuberkulosis, sehingga muncul sikap berhati-hati berlebihan, misalnya seperti menggasingkan penderita, enggan mengajak berbicara, dan kalau dekat penderita akan segara menutup hidung dan sebagainya.

Tujuan Penelitian : Penelitian ini bertujuan untuk mengetahui "Hubungan Dukungan Keluarga Dengan Kualitas Hidup Penderita Tuberkulosis"

Metode Penelitian : Metode penelitian ini menggunakan metode Literature Review. Pada penelitian ini terdapat 6 jurnal yang sudah di Screening dengaan kriteria Inklusi mulai dari jumlah sample 4 I-96 responden, dengan I studi design yaitu cross sectional, tahun terbit jurnal 2017-2020 dan menggunakan bahasa Indonesia.

Hasil : Berdasarkan hasil penelitian menggunakan Literature Review dari 6 jurnal yang di analisis didapatkan dukungan keluarga dan kualitas hidup responden kategori dominan baik dan hasil statistic dari 6 jurnal $p$ - value $0,00<0,05$ ada hubungan antara dukungan keluarga dengan kualitas hidup penderita tuberkulosis.

Kesimpulan : Hasil analisis dari 6 jurnal penelitian Literature Review bahwa semakin tinggi dukungan keluarga pada penderita TBC maka semakin baik tingkat kualitas hidup dan menunjukan bahwa ada hubungan yang sangat bermakna antara dukungan keluarga dengan kualitas hidup penderita tuberkulosis.
\end{abstract}

Kata Kunci:

Dukungan Keluarga

Kualitas Hidup

Penderita Tuberkulosis

\begin{abstract}
Background: Tuberculosis (TBC) is an infectious disease caused by the bacterium Mycobacterium tuberculosis. The phenomenon that is found in today's society is that there are still family members who are afraid to be close to someone who has tuberculosis, so that excessive caution appears, for example, such as alienating the patient, reluctant to talk, and if close the patient will immediately cover his nose and so on.

Research Objectives: This study aims to determine "The Relationship between Family Support and Quality of Life of Tuberculosis Patients".

Research Methods: This research method uses themethod Literature Review. In this study, there are 6 journals that have been screened withcriteria inclusion ranging from a sample of 4I-96 respondents, with I study design, namely cross sectional, published in 201 7-2020 journal and written in Indonesia.

Results: Based on the results of the study using a Literature Review of 6 journals analyzed, it was found that family support and quality of life of respondents were in the good dominant category andresults statistical from 6 journals $p$-value $0.00<0.05$ there was a relationship between family support and quality of life for tuberculosis patients. Conclusion: The results of the analysis of 6 research journals Literature Review that the higher the family support for TB patients, the better the level of quality of life and shows that there is a very significant relationship between family support and the quality of life of people with tuberculosis.
\end{abstract}

Keywords:

Family Support

Tuberculosis Patients. 


\section{PENDAHULUAN}

TBC adalah suatu penyakit menular yang disebakan oleh bakteri Mycobacterium tuberculosis, yang dapat menyerang berbagai organ, terutama paru. Penyakit ini bila tidak diobati atau pegobatannya tidak tuntas dapat menimbulkan komplikasi berbahaya hingga kematian (Kemenkes RI, 2016). Fenomena yang didapatkan di masyarakat sekarang ini masih ada anggota keluarga yang merasa takut berdekatan dengan seseorang yang menderita tuberkulosis, sehingga muncul sikap berhatihati berlebihan, misalnya seperti menggasingkan penderita, enggan mengajak berbicara, dan kalau dekat penderita akan segara menutup hidung dan sebagainya. Maka hal tersebut dapat menyebabkan penderita merasa tertekan dan dikucilkan dan dampaknya pada psikologis dapat menyebabkan stres dan mempengaruhi keberhasilan pengobatan yang dapat menurunkan kualitas hidupnya. tuberkulosis merupakan penyakit yang memerlukan waktu lama pada proses penyembuhan sehingga dapat menimbulkan stress situasional dalam keluarga.

Menurut (WHO) 2017 dalam (Kemenkes RI 2018) secara Global sebagian besar estimasi insiden tuberkulosis pada tahun 2016 berada pada Wilayah Asia Tenggara (45\%), Afrika (25\%) dan Pasifik Barat (17\%), sedangkan persentase pada daerah Mediterania Timur (7\%), Amerika (3\%) dan Eropa (3\%). (Global Tuberculosis Report) 2018 dalam (Kemenkes RI 2018) secara Global sebagian besar kasus tuberkulosis pada tahun 2018 berada pada Wilayah Asia Tenggara (44\%), Afrika (24\%) dan Pasifik Barat (18\%), sedangkan persentase pada daerah Mediterania Timur (8\%), Amerika (3\%) dan Eropa (3\%). Berdasarkan data (WHO 2020) Indonesia sekarang merupakan negara dengan penderita tuberkulosis kedua di dunia setelah India dimana pada tahun sebelumnya Indonesia masih menduduki peringkat ketiga di dunia, ini berarti penderita tuberkolosis mengalami kenaikan. Berdasarkan (Global Tuberculosis Report 2018) estimasi jumlah kasus tuberkulosis di Indonesia sebanyak
842.000 dengan $85 \%$ keberhasilan pengobatan disamping $32 \%$ kasus yang belum terlaporkan. Sedangkan (WHO) (Global Tuberculosis Programme 2020) menunjukan adanya peningkatan kasus tuberkulosis dimana estimasi jumlah kasus tuberkulosis di Indonesia meningkat sebanyak 2.000 jumlah kasus dari tahun sebelumnya sebanyak 843.000 menjadi menjadi 845.000 jumlah kasus dengan tingkat persentase keberhasilan yang mengalami penurunan sebanyak $2 \%$ dari yang sebelumnya $85 \%$ menjadi $83 \%$ tingkat keberhasilan pengobatan disertai dengan melonjaknya persentase kasus yang belum terlaporkan dari $32 \%$ menjadi $67 \%$. Penemuan kasus tuberkulosis Provinsi Kalimantan Tengah jumlah kasus tuberkulosis mengalami peningkatan ditemukan tahun 2017 sebanyak (2.84I kasus), tahun 2018 sebanyak (3.686 kasus) (Profil kesehatan indonesia 2017- 2018). Prevelensi kasus tertinggi tuberkulosis Provinsi Kalimantan Tengah pada tahun 2018 terjadi pada kelompok jenis kelamin diantaranya (2.369) laki-laki dan (I.317) perempuan. Penemuan jumlah kasus tuberkulosis di Kota Palangka Raya mengalami penurunan pada tahun 2017 (602 kasus), dan tahun 2018 (517 kasus) (Riskesdas, 2017-2018). Meskipun terjadi angka penurunan jumlah kasus tuberkulosis di Kota Palangka Raya, tuberkulosis termasuk penyakit kronis berbahaya yang harus ditangani dengan serius agar tidak terjadinya peningkatan penemuan kasus baru tuberkulosis.

Menurut (Suryani \& Zulham Efendi 2020 dalam Bura 2020) permasalahan yang sering terjadi adalah kurangnya kesadaran pasien untuk minum obat secara teratur sehingga TBC menjadi sulit untuk disembuhkan. Ketidak teraturan dalam mengkonsumsi obat ini dipengaruhi oleh faktor internal dan faktor eksternal, salah satu faktor internal pendidikan dan eksternalnya yaitu dukungan keluarga. Dukungan sosial yang berupa moral, emosional lainnya dimungkinkan memiliki hubungan dengan kesadaran pasien untuk minum obat secara teratur. Keseluruhan aspek dalam 
2 dukungan tersebut hanya dimungkinkan untuk terpenuhi lewat hubungan seseorang dengan orang disekitarnya dengan kata lain yakni hubungan keluarga. Kemenkes RI (2019) tingginya masalah tuberkulosis di Indonesia disebabkan diantaranya karena penemuan kasus dan pengobatannya secara tuntas masih kurang, dan lebih cepat penyebaran penyakitnya. Sebelum datang ke layanan kesehatan yang tepat, banyak orang mencari pengobatan di luar layanan kesehatan, termasuk mengobati sendiri. Penyakit TBC yang disebabkan terjadi ketika daya tahan tubuh menurun. Dalam perspektif epidemiologi yang melihat kejadian penyakit sebagai hasil interaksi antar tiga komponen pejamu (host), penyebab (agent), dan lingkungan (environment) dapat ditelaah faktor risiko dari simpulsimpul tersebut. Pada sisi pejamu, kerentanan terhadap infeksi Mycobacterium tuberculosis sangat dipengaruhi oleh daya tahan tubuh seseorang pada saat itu (Kemenkes RI 2018).

Solusi yang diberikan adalah pendekatan keluarga dengan memberikan edukasi tentang penyakit tuberkulosis. Serta peran dari tenaga kesehatan masyarakat dan promosi kesehatan dengan bekerja sama dengan lintas sektor baik tokoh agama/tokoh masyarakat, edukasi ke tempat pendidikan dan pelayanan kesehatan terkait. Penguatan peran (PMO) dan pelatihan bagi kader desa untuk meningkatkan keberhasilan kesembuhan penderita tuberkulosis. Keuntungan penderita yang mendapatkan dukungan sosial yang tinggi akan menjadi individu yang lebih optimis dalam menghadapi kehidupanya pada saat ini maupun yang akan datang. Berdasarkan hal tersebut maka sangat diperlukan adanya dukungan keluarga, karena dukungan keluarga sangat penting untuk penderita penyakit kronis sebab dukungan dari keluarga dapat mempengaruhi tingkah laku individu, seperti penurunan rasa cemas tidak berdaya dan putus asa yang pada akhirnya dapat meningkatkan status kesehatan. Berdasarkan latar belakang tersebut peneiliti tertarik untuk meneliti tentang hubungan dukungan keluarga dengan kualitas hidup penderita tuberkulosis.

Penelitian ini bertujuan untuk "Mengetahui hubungan dukungan keluarga dengan kualitas hidup penderita tuberkulosis".

\section{METODOLOGI}

Penelitian ini merupakan studi literature review atau tinjauan pustaka yang dimana bahwa dijelaskan literature review adalah analisis terintegrasi tulisan ilmiah yang terkait langsung dengan pertanyaan penelitian (Nursalam, 2020). Studi literature review merupakan studi yang dipakai untuk mengumpulkan data sekunder yang berhubungan atau terkait dengan topik tertentu yang bisa didapatkan dari berbagai sumber seperti buku, jurnal, internet dan pustaka lainnya. Metode penelitian dapat diartikan sebagai cara ilmiah untuk mendapatkan data yang valid dengan tujuan dapat ditemukan, dikembangkan, dan dibuktikan, suatu pengetahuan tertentu sehingga pada gilirannya dapat digunakan untuk memahami, memecahkan dan mengantisipasi masalah (Sugiyono, 2016). Desain penelitian ini dilakukan dengan pendekatan crosssectional. Penelitian cross-sectional adalah suatu penelitian untuk mempelajari dinamika korelasi antara faktor-faktor risiko dengan efek, dengan cara pendekatan, observasional, atau pengumpulan data. Penelitian cross-sectional hanya mengobservasi sekali saja dan pengukuran dilakukan terhadap variabel subjek pada saat penelitian (Notoatmojo, 20l0). Judul dalam penelitian ini adalah "hubungan dukungan keluarga dengan kualitas hidup penderita tuberkulosis”. Variabel independen "Dukungan Keluarga dan variabel dependen "Kualitas Hidup”.

\section{HASIL DAN PEMBAHASAN}

Hasil analisis dari 6 jurnal menujukan lebih dominan responden memiliki dukungan keluarga yang baik sebanyak 225 responden (53,9\%) dan buruk sebanyak I 88 responden (46\%), pada kualitas hidup menunjukan lebih dominan responden memiliki kualitas hidup yang 
baik sebanyak 250 responden (62\%) dan buruk sebanyak 213 responden (54\%). Berdasarkan hasil penelitian literature review dar 6 jurnal yang dianalisis tidak terdapat kesenjangan dan sejalan dengan teori yang ada. Dari 6 jurnal yang peneliti temukan semua, ada hubungan yang signifikan antara dukungan keluarga dengan kualitas hidup penderita tuberkulosis, dengan nilai kemaknaan ( $P$ value: $0,000<0,05$ ).

\section{KESIMPULAN}

Berdasarkan hasil analisis data sekunder dari 6 jurnal penelitian yang dilakukan oleh peneliti mengenai "Hubungan Dukungan Keluarga Dengan Kualitas Hidup Penderita Tuberkulosis". ada hubungan yang signifikan antara dukungan keluarga dengan kualitas hidup penderita tuberkulosis. Dukungan keluarga yang baik dikarenakan keluarga mengetahui dan sadar akan pentingnya memberikan dukungan kepada penderita agar meningkatkan minat pasien untuk menjalani pengobatan dan cepat sembuh dari penyakitnya. Kualitas hidup yang baik karena mendapatkan dukungan sosial yang tinggi dari anggota keluarga serta kesejahteraan materi, akan membangun rasa percaya diri dari penderita dan akan meningkatkan kualitas hidup yang baik. Berdasarkan hasil analisis oleh peneliti 6 jurnal berkaitan dengan penelitian penulis karena dapat menjelaskan dukungan keluarga dengan kualitas hidup penderita tuberkulosis, dapat di ambil kesimpulan bahwa semakin tinggi dukungan keluarga pada penderita TBC maka semakin baik tingkat kualitas hidup dan menunjukan bahwa ada hubungan yang sangat bermakna antara dukungan keluarga dengan kualitas hidup penderita tuberkulosis.

Saran untuk penelitian selanjutnya:

I. Hasil penelitian ini dapat digunakan sebagai perkembangan ilmu pengetahuan dan teknologi, sebagai kontribusi dalam pengaplikasian di bidang kesehatan masyarkat serta dapat menjadi alat dasar sebagai upaya untuk mengembangkan ilmu pada dukungan keluarga agar penderita TBC mendapatkan kualitas hidup yang baik.

2. Untuk Mahasiswa khususnya dalam ilmu kesehatan masyarakat diharapkan lebih banyak menggunakan jurnal terkait dari hasil literature review ini diharapkan bisa menjadi acuan atau referensi bagi peneliti selanjutnya dalam melakukan penelitian mengenai hubungan dukungan keluarga dengan kualitas hidup penderita tuberkulosis sehingga dapat meningkatkan pengetahuan khususnya pada penderita yang dukungan keluarga nya masih kurang.

\section{UCAPAN TERIMA KASIH}

Peneliti mengucapkan terima kasih kepada:

I. Bapak DR. dr. Andryansyah Arifin MPH. selaku Ketua Yayasan Eka Harap Palangka Raya yang telah menyediakan sarana dan prasarana kepada penulis dalam menempuh pendidikan di STIKES Eka Harap Palangka Raya.

2. Ibu Maria Adelheid Ensia, S.Pd., M.Kes. Selaku Ketua STIKES Eka Harap Palangka Raya yang telah menyediakan sarana dan prasarana kepada penulis dan mengikuti pendidikan di STIKES Eka Harap Palangka Raya.

3. Ibu Lensi Natalia Tambunan, SST, M.Kes. selaku Ketua Program Studi Sarjana Kesehatan Masyarakat STIKES Eka Harap Palangka Raya.

4. Ibu Rizki Muji Lestari, SST, M.Kes selaku Ketua Penguji yang telah bersedia meluangkan waktu untuk menguji skripsi ini.

5. Ibu Mariaty A. Sangkai, SPd, M.Kes.selaku Pembimbing I yang telah membantu dan membimbing saya dalam pembuatan skripsi ini, sehingga skripsi ini dapat terselesaikan tepat waktu.

6. Ibu Melisa Frisilia, S.Kep., M.Kes. selaku Pembimbing II yang juga telah membantu saya dalam meyelesaikan skripsi ini dan bersedia membagikan ilmunya dalam membantu saya menyelesaikan skripsi ini. 
7. Kepada kedua orang tua saya, terima kasih atas dukungan serta doa yang selalu diberikan kepada saya.

8. Egot yang comel yang selalu membantu dan memberikan semangat kepada saya

9. Seluruh rekan-rekan dan sahabat saya yang telah banyak membantu dalam menyelesaikan skripsi ini.

Semoga bantuan serta budi baik yang telah diberikan kepada peneliti, mendapatkan balasan dari Allah SWT. Besar harapan peneliti agar skripsi ini dapat bermanfaat.

\section{REFERENSI}

I. Kemenkes RI. (20I6). Info data dan informasi Tuberculosis Temukan Obati Sampai Sembuh (p. 12).

2. Kemenkes RI. (20I8). Infodatin Tuberkulosis. Kementerian Kesehatan RI, I-8.

3. Provinsi, L., \& Tengah, K. (20I8). Riskesdas20/8. https://ejournal2.litbang.kemkes.go.id/index.php/lp b/article/view/3759

4. Suryani, U., \& Zulham Efendi. (2020). Dukungan Keluarga Berhubungan dengan Harga Diri Pada Family Supporting Relationships With Self-Esteem in Patients With Pulmonary Tuberculosis. Jurnal IImu Keperawatan Jiwa, 3(I), 53-58.

5. Kemenkes RI. (2019). Profil Kesehatan Indonesia 2018 [Indonesia Health Profile 2018]. http://www.depkes.go.id/resources/download/pus datin/profil-kesehatan-indonesia/Data-danInformasi_Profil-Kesehatan-Indonesia-2018.pdf

6. Nursalam. (2020). Literature Systematic Review pada Pendidikan Kesehatan.

7. Sugiyono. (20I6). Metode Penelitian Kuantitatif, Kualitatif, R\&D. IKAPI.

8. Notoatmodjo, S. (2010). Metodologi Penelitian Kesehatan (Rineka Cip). 